(C) Journal «Agrarian History», № 2, 2020.

Publication date: April 5, 2020

\title{
THE ROLE OF FERTILIZERS IN IMPROVING SOIL FERTILITY IN THE RUSSIAN PROVINCE
}

\author{
Vladimir Fursov ${ }^{1}$ \\ ${ }^{1}$ Doctor of Historical Sciences, Professor, Voronezh State Pedagogical University, Lenin street, 86, \\ Voronezh, Russia
}

\begin{abstract}
The article discusses the processes of improving soil fertility by applying various types of fertilizers. Crop production in Russia and many other countries is characterized by a low level of stability of agrocenoses and poor phytosanitary condition of soils. This is confirmed by the wide spread of weed vegetation. In a number of regions, a new phenomenon has been discovered - non-infectious physiological diseases of plants associated with a violation of the diet, the balance of nutrients in the soil and extreme weather conditions.

Plant resistance to these pathogens is higher at doses and ratios of nutrients close to optimal for ensuring their productivity. An analysis of the literature shows that the resistance of plants to root rot and existing diseases is significantly higher if nitrogen fertilizers are used in physiologically reasonable doses recommended by the regional system of agriculture.
\end{abstract}

Keywords: agriculture, weed, plant, farmer.

\section{INTRODUCTION}

At present, according to the agrochemical service in Russia, $45 \%$ of arable land is characterized by a low humus content, $23 \%$ - phosphorus deficiency and $9 \%$ - potassium. According to experts' forecasts, the removal of nutrients from the soil may exceed their intake with fertilizers by several times. Therefore, in the federal target program "Preservation and restoration of soil fertility of agricultural lands and agricultural landscapes as a national treasure of Russia for 2007-2020" and the State Program "Development of agriculture and regulation of markets for agricultural products, raw materials and food for 2008-2012" among the main goals the task of preserving and reproducing natural resource potential and increasing soil fertility has been determined.

The components of increasing soil fertility are a combination of a wide variety of factors that affect the potential return of agricultural land in the form of crops. Among the many soil varieties, a special place is occupied by peat soils and soils of worked-out peatlands, which perform a special landscape-hydrological and geochemical function of the earth. In the process of long-term use, some of them have lost their natural properties due to the intensive mineralization of organic matter and have lost their ecological stability. Preventing the degradation process and increasing the fertility of such soils is an urgent and timely task. 


\section{METHODOLOGY AND RESULTS}

For the first time, a comparative assessment of the main indicators of soil fertility and the energy state of organic matter in floodplain soil in various areas of agricultural use was carried out. Indicators characterizing the agroecological state of agricultural soils in the Voronezh region (the amount of labile humic substances, bulk density, soil structure, biomass content of soil microorganisms, respiration rate and cellulose-decomposing soil activity) have been determined. In the Voronezh region, a positive effect of the use of organic and mineral fertilizers on the microbiological activity of arable land was established: on average, the microbiological activity after the application of mineral fertilizers increased by $7 \%$ (no aftereffect was noted), and with the combined use of organic and mineral fertilizers up to $30 \%$ on average by $17 \%$ ). Studies have shown that different types of soil, type of agricultural use, fertilization and cultivated crops do not affect the ratio between the components of soil organic matter: humus carbon is $95-97 \%$, non-humified organic matter is $3-5 \%$. Fertilization has a significant effect on the ratio between the labile and inert parts of humus.

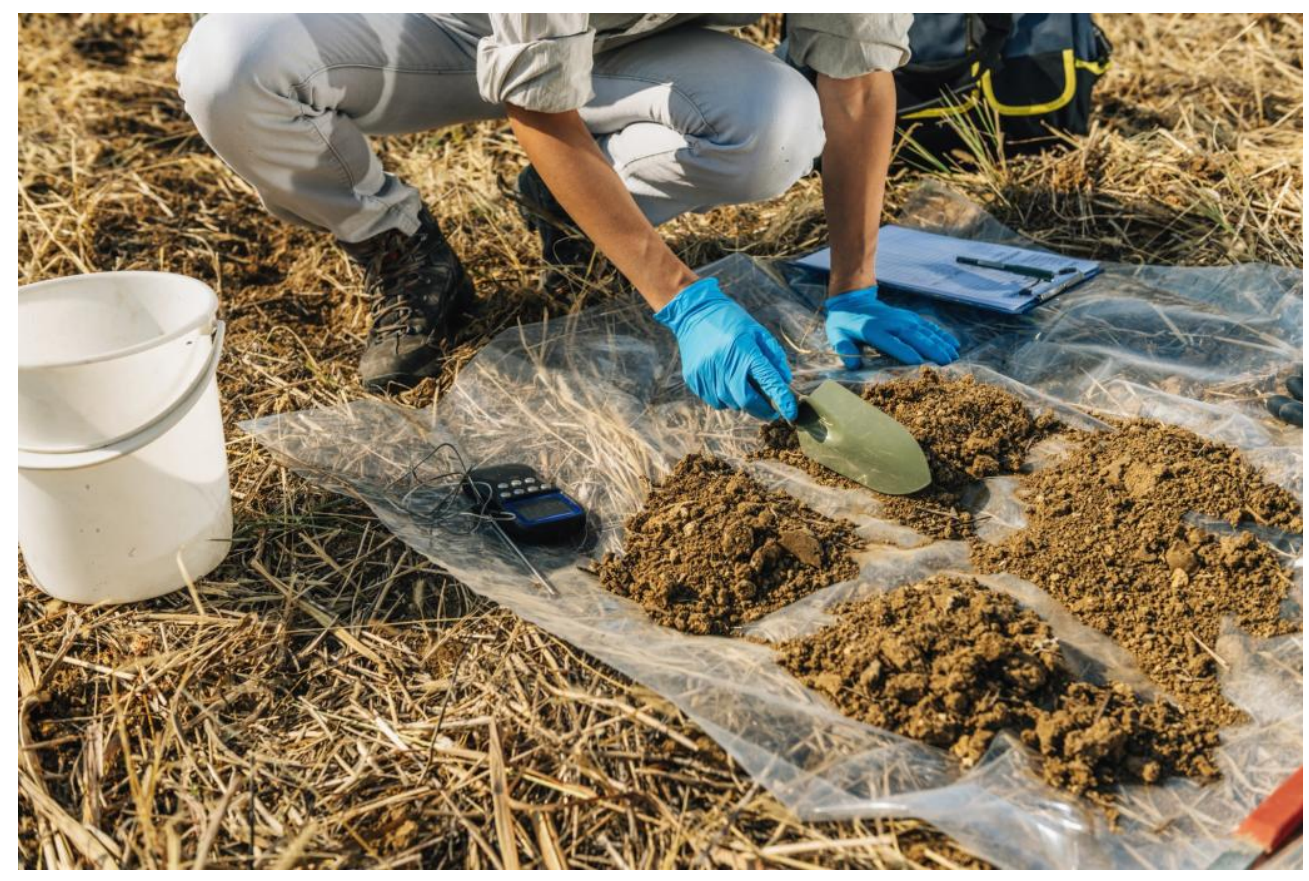

The combined application of organic and mineral fertilizers increases the content of labile humic substances (up to $6.6 \mathrm{mgC} / \mathrm{g}$ of soil) and reserves of non-humified organic matter (up to $8 \mathrm{t} / \mathrm{ha}$ ), as well as energy reserves in these components of organic matter. The aftereffect of fertilization increases the content of non-humified organic matter (up to $4.5 \mathrm{t} / \mathrm{ha}$ ) and improves its energy characteristics. 


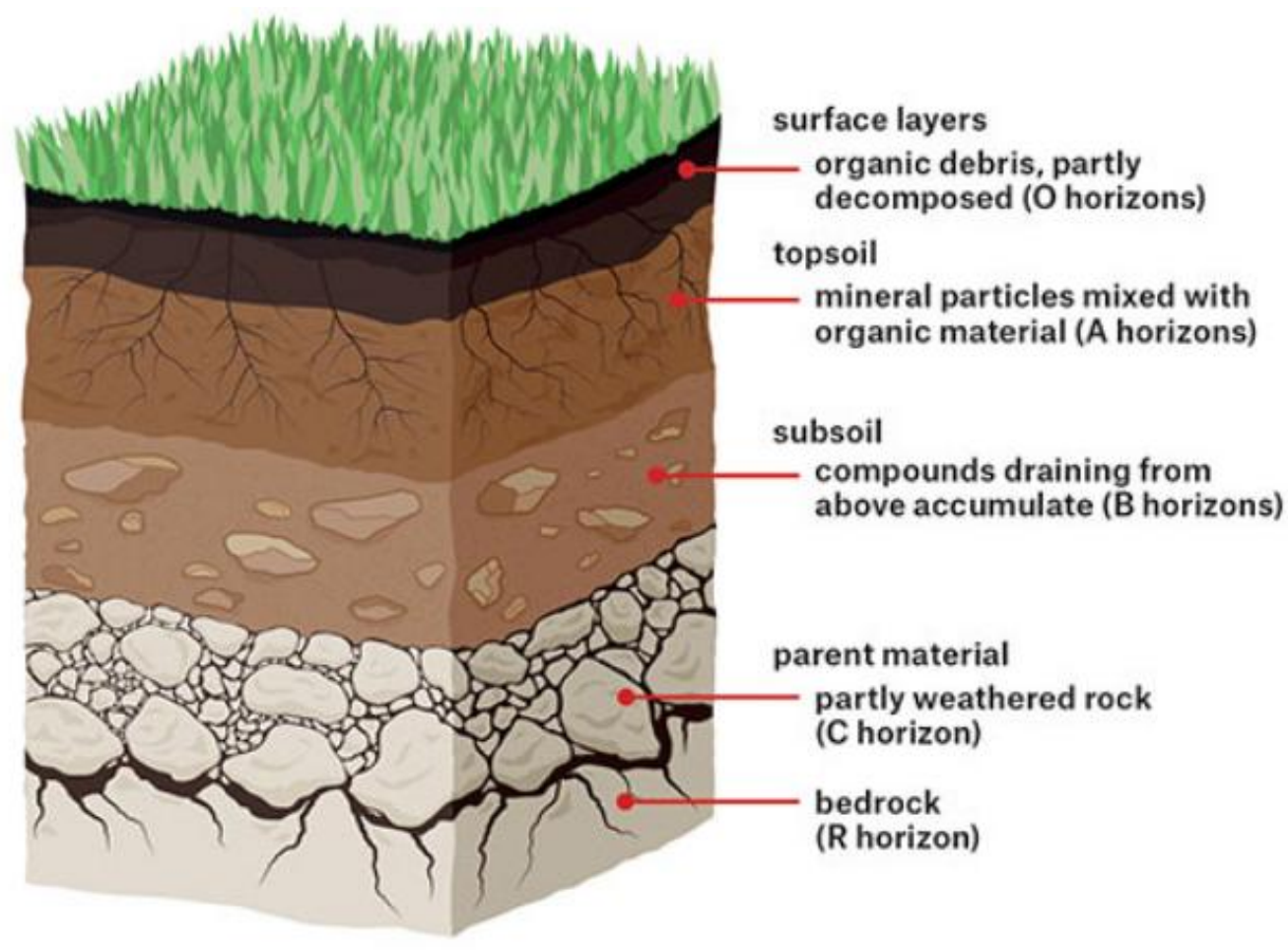

The microbiological activity is influenced by the use of organic and mineral fertilizers. At the same time, an increase in the intensity of respiration (up to $104 \mathrm{mg} \mathrm{CO} 2 / \mathrm{kg}$ ), the content of C-biomass of soil microorganisms (up to $704 \mathrm{mg} / \mathrm{kg}$ ) and cellulose-decomposing soil activity (up to $28 \%$ ).

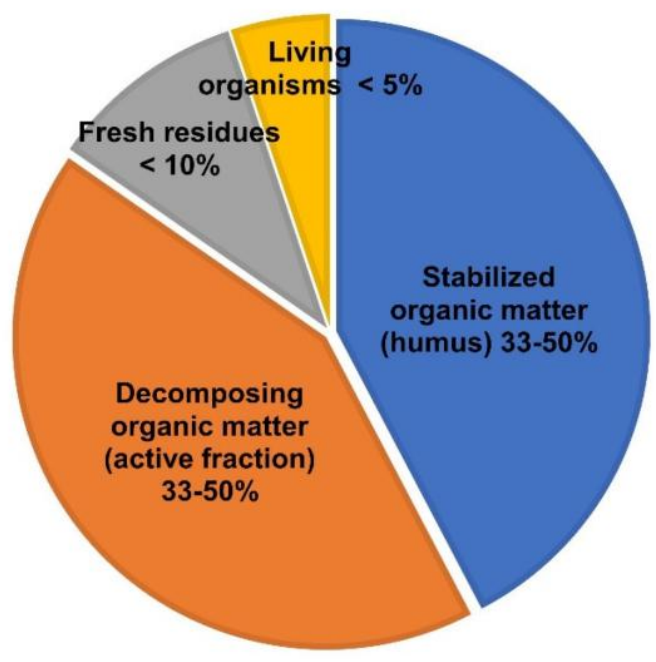

The aftereffect of the influence of fertilizers was noted only with the combined use of organic and mineral fertilizers. 


\section{CONCLUSION}

Studies have shown that in the Voronezh region it is advisable to conduct agroecological monitoring in intensively cultivated areas. On the basis of the data obtained, the dynamics of soil fertility indicators is analyzed for various land use systems.

To characterize soil fertility, additional indicators should be introduced: the content of labile humic substances, the reserves of non-humified organic matter.

In conditions of excessive moisture, one of the main factors limiting the yield of agricultural crops is soil moisture, therefore, special attention should be paid to the state of the drainage network.

\section{REFERENCE LIST}

Kiryushin V.I. (1993) The concept of optimization of the regime of organic matter of soils in agricultural landscapes. M .: Publishing house of Moscow Agricultural Academy. 99 p. (in Russ).

Kovalev N.G. (2002) Traditional organic fertilizers and mineral fertilizers on the reclaimed soils of the NonBlack Earth Region: Textbook. manual for universities. Tver. 212 p. (in Russ). Russ).

Kulakovskaya T.N. (1990) Optimization of the agrochemical system of soil plant nutrition. M. 218 p. (in

Lukin S.M. (1998) The effect of long-term use of various fertilizer systems on crop yields and soil agrochemical properties. Scientific bases and technologies for reproduction of soil fertility and the use of organic fertilizers. Collection of scientific papers. Issue 1. M. Pp. 41-50. (in Russ). Russ).

Maslov B.S. (1998) Integrated land reclamation: formation and development. M. RAAS. Pp. 234-245. (in

Mukha D.V. (2003) Soil fertility and human development. Problems of Soil Evolution: Materials of the IV All-Russian Conf. Pushchino, IPH and BPP RAS. Pp. 23-27. (in Russ).

Pannikov V.D. (1981) Theory and practice of increasing soil fertility. Vestn. s.-kh. science. №. 2. Pp. 1423. (in Russ).

Russell E. (1955) Soil Science and Plant Growth Condition. M. Publishing house of foreign literature. 624 p. (in Russ).

Sibirtsev N.M. (1951) Selected Works. Volume 1 Soil Science. M. Publishing house of agricultural literature. 472 p. (in Russ).

Skoropanov S.G. (1961) Development and use of peat-bog soils. Minsk: Ed. Academy of Agricultural Sciences. 249 p. (in Russ).

Kupchinskaya V. N. (2000) Influence of long-term use of mineral fertilizers and manure on soil response and crop rotation productivity. Problems of plant nutrition and the use of fertilizers in modern conditions. Pp. 265267. (in Russ). 


\title{
РОЛЬ УДОБРЕНИЙ В ПОВЫШЕНИИ ПЛОДОРОДИЯ ПОЧВ В РОсСИЙскОЙ пРОвИнциИ
}

\author{
Владимир Фурсов 1 \\ ${ }^{1}$ Доктор исторических наук, профрессор, Воронежский государственный педагогический \\ университет, ул. Ленина, 86, Воронеж, Россия
}

\begin{abstract}
Аннотация
В статье рассматриваются процессы повышения плодородия почв путем внесения различных видов удобрений. Растениеводство в России и во многих других странах характеризуется низким уровнем устойчивости агроценозов и плохим фитосанитарным состоянием почв. Это подтверждается широким распространением сорной растительности. В ряде регионов было открыто новое явление неинфекционные фризиологические заболевания растений, связанные с нарушением рациона питания, баланса питательных веществ в почве и экстремальными погодными условиями.

Устойчивость растений к этим патогенам выше при дозах и соотношениях питательных веществ, близких к оптимальным для обеспечения их продуктивности. Анализ литературы показывает, что устойчивость растений к корневым гнилям и существующим болезням значительно выше при использовании азотных удобрений в физиологически обоснованных дозах, рекомендованных региональной системой сельского хозяйства.
\end{abstract}

Ключевые слова: сельское хозяйство, сорняк, растение, фермер. 